\title{
Molecular Characterization and Genotypic and Genotypic Evaluation of Antibiotic Resistance of Methicillin Resistant- staphylococcus Aureus Isolated From Raw Meat
}

Roya Chabi ( $\sim$ royachabi@yahoo.com)

Islamic Azad University

\section{Data Article}

Keywords: Methicillin-resistant Staphylococcus aureus, Raw meat, Panton-Valentine Leukocidin, SCCmec types, Antimicrobial resistance properties.

Posted Date: September 29th, 2020

DOI: https://doi.org/10.21203/rs.3.rs-82665/v1

License: (c) (i) This work is licensed under a Creative Commons Attribution 4.0 International License. Read Full License 


\section{Abstract}

Methicillin-resistant Staphylococcus aureus (MRSA) is considered to be one of the most important causes of food-borne diseases. The present investigation was done to assess the phenotypic and genotypic characterization and distribution of Staphylococcal cassette chromosome mectypes and Panton-Valentine leukocidin gene in the MRSA strains isolated from raw meat samples. Six-hundred and eighty meat samples were collected and cultured. MRSA strains were subjected to disk diffusion and Polymerase Chain Reaction. One-hundred and thirty-five out of $680(18.38 \%)$ raw meat samples were positive for $S$. aureus. Seventy-nine out of 125 (63.20\%) S. aureus strains were determined as MRSA. Raw sheep meat samples (75\%) had the highest prevalence of MRSA, while raw camel had the lowest (50\%). Fifty-eight out of 79 (73.41\%) MRSA strains harbored the $P V L$ gene. SCCmec IVa (39.65\%), V (22.41\%) and III (10.34\%) were the most commonly detected types in the MRSA strains. MRSA strains harbored the highest prevalence of resistance against penicillin (100\%), tetracycline (100\%), gentamicin (65.51\%) and erythromycin (56.89\%). AadA1 (58.62\%), tetK (56.89\%), msrA (41.37\%) and vatA (36.20\%) were the most commonly detected antibiotic resistance genes. Simultaneous presence of $P V L$ and antibiotic resistance genes in multi-drug resistant MRSA strains specifies significant public health problem.

\section{Introduction}

Staphylococcus aureus(S. aureus) is Gram-positive, catalase positive, and cocci-shaped bacterium typically originate from nose and respiratory tract and on the skin. It is mainly associated with nosocomial and community-acquired infections and foodborne diseases (Kadariya et al. 2014). S. aureus is a causative agents for about 241,000 food-borne illnesses per year in the United States (Scallan et al. 2011). Meat is one of the most important food stuffs related to the Staphylococcal food-borne diseases all around the world (Beneke et al. 2011; Hanson et al. 2011; Pu et al. 2009; Weese et al. 2010). High prevalence of $S$. aureus strains has also been reported in different types of meat samples (Hasanpour Dehkordi et al. 2017; Madahi et al. 2014; Momtaz et al. 2013; Safarpoor Dehkordi et al. 2018; Safarpoor Dehkordi et al. 2017a).

Staphylococcal foodborne diseases are primarily related to the emergence of antibiotic resistance (De Boer et al. 2009). It has been documented that about $50 \%$ of strains of this bacterium were considered to be methicillin-resistant $S$. aureus (MRSA) (De Boer et al. 2009; Johnson 2011; Morell and Balkin 2010; Shen et al. 2013). A survey which was conducted on the United States revealed an annual estimate of 94,000 MRSA infections with nearly $20 \%$ mortality rate (Klevens et al. 2007). Presence of certain antibiotic resistance genes such as mecA (methicillin), linA (lincosamides), $m s r A$ and $m s r B$ (macrolides), vatA, vatB and vatC (acetyl transferase genes and streptogramin A), ermA, ermB and ermC (macrolide-lincosamide-streptogramin $B$ ), tetK and tetM (tetracycline) and aacA-D (aminoglycosides) is one of the most important mechanisms for occurrence of antibiotic resistance (Argudín et al. 2010; Momtaz and Hafezi 2014). The gene for methicillin resistance, $m e c A$, is carried on a 21- to 67-kb element,

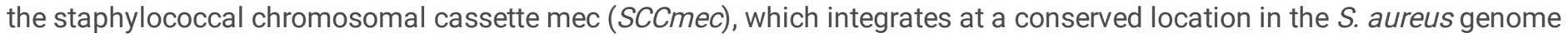
(Shukla et al. 2012). SCCmec genetic element characterized by the presence of two essential genetic markers (the mec and the ccr gene complexes). SCCmec elements are classically classified into types I, II, III, IV and V according to the nature of the mec and ccrgenes (Ferreira et al. 2013; Turlej et al. 2011). Type IV of the SCCmec genetic element is divided to IVa, IVb, IVc and IVd alleles (Ferreira et al. 2013; Turlej et al. 2011). The frequent recovery of staphylococcal isolates that produce leukocidal toxins from the cases of foodborne diseases and clinical infections, suggests that the Panton-Valentine Leukocidin (PVL) is a virulence marker with significant role in the pathogenicity of staphylococcal diseases (Ogata et al. 2012; Shrestha et al. 2014; Velasco et al. 2014).

Rendering the high importance of MRSA strains as a foodborne pathogen, the current research was done to study the prevalence rate, distribution of SCCmec types and PVL gene and antimicrobial resistance properties of the MRSA strains isolated from raw ruminant, poultry and fish meat samples in Iran.

\section{Methods}

Sampling procedure

Page 2/16 
From March to September 2017, a total of 680 raw meat samples including beef $(n=150)$, goat $(n=80)$, sheep $(n=100)$, camel $(n=60)$, chicken $(n=80)$, turkey $(n=50)$, quail $(n=50)$, ostrich $(n=50)$ and fish $(n=60)$ were randomly purchased from butchers of several geographic regions of Iran. Samples were immediately transferred to laboratory in cooler with ice-packs.

\section{Isolation and identification of S. aureus and MRSA strains}

Each sample was aseptically weighed in an analytical balance and twenty-five grams were transferred into a sterile plastic bag. Then, $225 \mathrm{~mL}$ of buffered peptone water (Merck, Germany) was added and homogenized in a Stomacher Bagmixer 400W (Interscience, Saint-Nom, France) for two min. Five milliliter aliquot of the enriched homogenate was transferred into $50 \mathrm{~mL}$ Trypticase Soy Broth (TSB, Merck, Germany) supplemented with $10 \% \mathrm{NaCl}$ and $1 \%$ sodium pyruvate. After incubation at $35{ }^{\circ} \mathrm{C}$ for $18 \mathrm{~h}$, a loopful of the culture was plated onto Baird-Parker agar supplemented with egg yolk tellurite emulsion (Merck, Germany) and incubated overnight at $37^{\circ} \mathrm{C}$. Black shiny colonies surrounded by 2 to 5 -mm clear zones were further identified on the basis of some biochemical tests (Fijałkowski et al. 2016).

Cefoxitin $(30 \mu \mathrm{g})$ and oxacillin $(1 \mu \mathrm{g})$ susceptibility tests were used to distinguish the MRSA strains from $S$. aureus isolates of meat samples. All tests were performed using the guidelines of the Clinical and Laboratory Standards Institute (CLSI) (CLSI 2007). MRSA isolates were identified another time using the Polymerase Chain Reaction (PCR)-based amplification of mecA gene (Safarpoor Dehkordi et al. 2017a). MRSA strains were sub-cultured on TSB (Merck, Germany) and further incubated for 48 $\mathrm{h}$ at $37^{\circ} \mathrm{C}$. Genomic Deoxyribonucleic acid (DNA) was extracted from bacterial colonies using the DNA extraction kit (Thermo Fisher Scientific, Germany) according to manufacturer's instruction. After extraction, the DNA samples were quantified (NanoDrop, Thermo Scientific, Waltham, MA, United States (USA)), their purity checked (A260/A280), and their concentrations adjusted to 50 nanogram per microliter $(\mathrm{ng} / \mu \mathrm{L})$.

\section{Antibiotic resistance analysis}

Pattern of antimicrobial resistance was studied using the simple disk diffusion technique. The Mueller-Hinton agar (Merck, Germany) medium was used for this purpose. Antibiotic resistance pattern of MRSA strains was studied against 10 commonly used antibiotic agents including penicillin $(10 \mu \mathrm{g} / \mathrm{disk})$, gentamicin $(10 \mu \mathrm{g} /$ disk), azithromycin $(15 \mu \mathrm{g} / \mathrm{disk})$, erythromycin (15 $\mu \mathrm{g} /$ disk), tetracycline (30 $\mu \mathrm{g} /$ disk), doxycycline $(30 \mu \mathrm{g} / \mathrm{disk})$, ciprofloxacin $(5 \mu \mathrm{g} / \mathrm{disk})$, clindamycin $(2 \mu \mathrm{g} /$ disk), trimethoprimsulfamethoxazole (25 $\mathrm{gg} /$ disk), and chloramphenicol (30 $\mu \mathrm{g} /$ disk) (Oxoid, UK). Method was done according to the principles of CLSI guidelines (CLSI 2012). The diameter of the zone of inhibition produced by each antibiotic disc was measured and interpreted using the CLSI zone diameter interpretative standards (CLSI 2012). S. aureus American Type Culture Collection (ATCC) 25923 and Escherichia coli ATCC 25922 were used as quality control organism in antimicrobial susceptibility determination.

Detection of antibiotic resistance genes and SCCmec types

Table 1 represents the oligonucleotide primers and PCR conditions used for amplification of antibiotic resistance genes and SCCmec types amongst MRSA strains isolated from various types of raw meat (Lina et al. 1999; Strommenger et al. 2003; Zhang et al. 2005). Additional PCR method was used to detect the PVL gene amongst the MRSA strains isolated from different types of meat samples (Yamasaki et al. 2005). A programmable DNA thermo-cycler (Eppendorf Mastercycler 5330, EppendorfNethel-Hinz GmbH, Hamburg, Germany) was used in all PCR reactions. All runs included a negative DNA control consisting of sterile PCR grade water (Thermo Fisher Scientific, Germany) and positive DNA control consisting of positive DNA of each target gene. Fifteen microliters of amplified PCR products were subjected to electrophoresis in a $2 \%$ agarose gel in $1 \times$ Tris-borateEthylenediamine tetraacetic acid (EDTA) (TBE) buffer at 90 V for 30-40 min, stained with SYBR Green (Thermo Fisher Scientific, Germany).

\section{Statistical analysis}

Statistical analysis was done using the Statistical Package for the Social Sciences (SPSS) 25.0 statistical software (SPSS Inc., Chicago, IL, USA). Chi-square test and Fisher's exact two-tailed test were used to assess any significant relationship for 
prevalence of MRSA strains and their antibiotic resistance and molecular characters between different types of samples. $P$ value $<0.05$ was considered as statistical significant level.

\section{Results}

Incidence of S. aureus, MRSA and PVL gene

Table 2 represents the distribution of $S$. aureus, MRSA strains and $P V L$ gene in different types of raw meat samples. Onehundred and thirty-five out of 680 (18.38\%) raw meat samples were positive for $S$. aureus strains. Raw sheep samples (28\%) had the highest prevalence of $S$. aureus strains, while raw fish samples had the lowest (1.66\%). Statistically significant difference was seen between type of samples and prevalence of $S$. aureus strains $(P<0.05)$. MecA gene was identified in all MRSA strains. Seventy-nine out of 125 (63.20\%) S. aureus strains were determined as MRSA strains. There were no MRSA strains in fish samples. Raw sheep samples (75\%) had the highest prevalence of MRSA strains, while raw camel meat samples had the lowest (50\%). Statistically significant difference was also seen between type of samples and prevalence of MRSA strains $(P<0.05)$. Fifty-eight out of 79 (73.41\%) MRSA strains harbored the $P V L$ gene. MRSA strains isolated from raw sheep meat samples had the highest prevalence of the $P V L$ gene (95.23\%), while those of quail had the lowest (33.33\%). Statistically significant difference was also seen between type of samples and distribution of the $P V L$ gene $(P<0.05)$.

\section{Distribution of SCCmec types}

Table 3 represents the distribution of SCCmec types in MRSA strains isolated from various types of raw meat samples. SCCmecIVa (39.65\%), V (22.41\%) and III (10.34\%) were the most commonly detected types in the MRSA strains isolated from various types of raw meat samples. Raw sheep meat samples had the highest and most diverse distribution of SCCmec types. Statistically significant difference was also seen between type of samples and distribution of the SCCmec types $(P<0.05)$.

\section{Antibiotic resistance pattern of MRSA strains}

Table 4 represents the antibiotic resistance pattern of MRSA strains isolated from various types of raw meat samples. MRSA strains harbored the highest prevalence of resistance against penicillin (100\%), tetracycline (100\%), gentamicin (65.51\%), erythromycin (56.89\%) and trimethoprim-sulfamethoxazole (55.17\%). MRSA strains exhibited the lowest prevalence of resistance against chloramphenicol (25.86\%) and clindamycin (29.31\%). Statistically significant difference was seen in the prevalence of antibiotic resistance between different types of raw meat samples $(P<0.05)$.

\section{Distribution of antibiotic resistance genes}

Table 5 represents the distribution of antibiotic resistance genes amongst the MRSA strains isolated from various types of raw meat samples. AadA1 (58.62\%), tetK (56.89\%), msrA (41.37\%) and vatA (36.20\%) were the most commonly detected antibiotic resistance genes amongst the MRSA strains isolated from various types of raw meat samples. Distribution of vatC (3.44\%), $m s r B(10.34 \%)$ and $\operatorname{vatB}(12.06 \%)$ were lower than other detected antibiotic resistance genes. Statistically significant difference was seen in the distribution of antibiotic resistance genes between different types of raw meat samples $(P<0.05)$.

\section{Discussion}

MRSA was first identified in 1961, immediately after the introduction of methicillin in clinical settings (Barber 1961). MRSA is widely accepted to be the most significant multi-drug resistant human pathogen (Hasanpour Dehkordi et al. 2017; Madahi et al. 2014; Momtaz et al. 2013; Safarpoor Dehkordi et al. 2018; Safarpoor Dehkordi et al. 2017a).

The present research was done to assess the phenotypic and genotypic characterization of antibiotic resistance and study the distribution of SCCmec types and PVL gene in the MRSA strains isolated from ruminants, poultries and fish meat samples. Zero prevalence rate of MRSA in fish meat samples is may be due, in part, to the presence of specific primary bacterial flora in fish and low ability of $S$. aureus to compete. Low prevalence of MRSA strains in camel meat samples is may be due the fact that camel's slaughter is done in specific slaughterhouses with high hygienic conditions. Higher pH level of sheep and goat meat 
than beef (Lazzaroni et al. 2007) is probably caused higher ability of $S$. aureus strains to growth and survival. Similar prevalence rate of MRSA strains was reported by Pu et al. (2009) (United States) (Pu et al. 2009), Huber et al. (2009) (Switzerland) (Huber et al. 2010), Lin et al. (2010) (Korea) (Lim et al. 2010) and Agwu Ulu et al. (2014) (Nigeria) (Agwu Ulu et al. 2014). Hasanpour Dehkordi et al. (2017) (Hasanpour Dehkordi et al. 2017) reported that the prevalence of MRSA strains in raw beef, sheep, goat and camel meat samples collected from Iran were $16.00 \%, 24.00 \%, 20.40 \%$ and $10.00 \%$, respectively which was similar to our findings. Raw meat may contain MRSA as a result of carcass contamination during slaughtering. Bhargava et al. (2011) (Bhargava et al. 2011) reported that 65 out of 289 raw meat samples (22.5\%) collected from Michigan, USA were positive for $S$. aureus: 32 beef (20.5\%), 19 chicken (25.0\%), and 14 turkey (24.6\%). They showed that 6 samples, consisting of 2 beef (1.30\%), 3 chickens (3.90\%) and 1 turkey (1.70\%), were positive for MRSA which was entirely lower than our results. Febler et al. (2011) (Feßler et al. 2011) showed that the prevalence of MRSA strains in turkey, chicken, pork and beef samples were $35.30 \%, 16 \%$, $15.20 \%$ and $10.60 \%$, respectively. Additionally, prevalence of MRSA strains in raw meat samples collected from Turkey (Gundogan et al. 2005), Egypt (Karmi 2013), Germany (Richter et al. 2012) and Denmark (Tang et al. 2017) were 30\%, 40.80\%, $71.50 \%$ and $52.00 \%$, respectively. Role of food handlers in transmission of MRSA strains was reported previously by Agwu Ulu et al. (2014) (Agwu Ulu et al. 2014).

High prevalence of $P V L$ gene in the MRSA strains poses an important public health threat. As far as we know, the present study is the first report of detection of the PVL gene in the MRSA strains of beef, sheep and chicken meat samples. Previously published data reported that majority of $P V L$-positive $S$. aureus strains were associated with skin and soft tissue infections (Holmes et al. 2005). Thus, PVL-positive MRSA strains may originate from infected staffs and meat inspectors in slaughterhouses. Presence of the $P V L$ gene in the $S$. aureus strains isolated from food samples has been reported previously (Abdalrahman et al. 2015; Holmes et al. 2005; Lozano et al. 2009).

SCCmec $I V$ and $V$ had the highest distribution in the MRSA isolates. MRSA is often sub-categorized as Health-care Associated MRSA (HA-MRSA) and Community Associated MRSA (CA-MRSA). CA-MRSA strains carry SCCmec type $I V$ or $V$, whereas the majority of HA-MRSA strains carry SCCmec type I, II or III (Asghar 2014). Thus, majority of MRSA strains isolated from raw meat samples of the present investigation were CA-MRSA. However, some of them were originate from the hospital environment and are recognized as HA-MRSA. Higher prevalence of SCCmec types $I V$ in beef and pork samples was also reported by Jackson et al. (2013) (Jackson et al. 2013). In a study which was conducted by Vossenkuhl et al. (2014) (Vossenkuhl et al. 2014) most of the MRSA strains of turkey meat samples carried SCCmec V (58.10-71.90\%), followed by type IVa (19-27\%) which was similar to our results. High prevalence of SCCmec IV and V in foods with animal origin have also been reported previously (Argudín et al. 2010; Bhargava et al. 2011; Kreausukon et al. 2012). Therefore, raw meat samples may be the sources of CA-MRSA with high prevalence of SCCmec IV and V.

MRSA strains harbored the highest prevalence of resistance against penicillin, tetracycline, gentamicin, erythromycin and trimethoprim-sulfamethoxazole antibiotic agents. Additionally, aadA1, tetK, msrA and vatA were the most commonly detected antibiotic resistance genes. Thus, phenotypic characters of antibiotic resistance of MRSA strains were approved by the genotypic characterization. Resistance levels found in this study can explain by the indiscriminate use of antimicrobials in humans treating diseases, which is a worrying trend. Hasanpour Dehkordi et al. (2017) (Hasanpour Dehkordi et al. 2017) reported that MRSA strains isolated from raw meat samples had high prevalence of resistance against ampicillin (100\%), ceftriaxone (80.00\%), amoxicillin-clavulanic acid (50.00\%), lincomycin (61.20\%), tetracycline (55.00\%), gatifloxacin (96.80\%), minocycline (51.20\%), cotrimoxazole (45.60\%), clindamycin (54.30\%), azithromycin (48.10\%), erythromycin (37.50\%), oxacillin (76.20\%) and penicillin (100\%) antibiotic agents. Momtaz et al. (2013) (Momtaz et al. 2013) reported that the S. aureus strains isolated from raw meat samples harbored the highest prevalence of resistance against tetracycline (97.50\%), methicillin (75.60\%), sulfamethoxazole (31.70\%), trimethoprim (31.70\%), streptomycin (31.70\%), gentamicin (29.20\%), enrofloxacin (28.00\%), ampicillin (26.8\%), chloramphenicol (20.70\%), and cephalothin (17.00\%) antibiotic agents. They also showed that the prevalence of $m e c A, m s r A, m s r B$, aacA-D, tetK and tet $M$ antibiotic resistance genes in the $S$. aureus strains were $82.92 \%, 34.14 \%$, 47.56\%, 39.02\%, 52.43\% and 46.34\%, respectively. Shahraz et al. (2012) (Shahraz et al. 2012) revealed that prevalence of antibiotic resistance in the $S$. aureus strains isolated from meat products against methicillin, erythromycin, penicillin G, cefazolin, ciprofloxacin, vancomycin and amoxiclav antibiotic agents were $89.00 \%, 20.30 \%, 18.70 \%, 15.60 \%, 14.00 \%, 26.60 \%$ and $12.50 \%$, respectively. Another similar study (Udo et al. 2009) revealed that the prevalence of resistance of $S$. aureus strains 
against penicillin G, tetracycline, erythromycin, clindamycin, trimethoprim, kanamycin, streptomycin and ciprofloxacin were $82 \%$, $19 \%, 2.50 \%, 2 \%, 7.50 \%, 2.50 \%, 1.50 \%$ and $1.50 \%$, respectively. High prevalence of resistance of MRSA strains against tetracycline, penicillin, ampicillin, and erythromycin was also reported by Waters et al. 2011 (Waters et al. 2011). Similar antibiotic resistance patterns especially against human-based antibiotic agents were also reported in the $S$. aureus and MRSA strains isolated from foods with animal origins and especially meat samples from Italy (Paludi et al. 2011), Nigeria (Fowoyo and Ogunbanwo 2017), Brazil (Kroning et al. 2016), Iran (Safarpoor Dehkordi et al. 2017b), USA (Jackson et al. 2013) and Egypt (Sallam et al. 2015). Chajęcka-Wierzchowska et al. (2017) (Chajęcka-Wierzchowska et al. 2017) reported the high prevalence of tetracycline (tetK, tetM, tetL) and methicillin ( $m e c A)$ antibiotic resistance genes in the $S$. aureus strains isolated from ready to eat food samples. Ma et al. (2018) (Bartter et al. 2018) revealed that $S$. aureus strains isolated from different types of food samples in China harbored the high distribution of $\beta$-lactams (blaTEM, blaZ, blaOXA and mecA), aminoglycosides (aac6/aph2"), tetracyclines (tet $A$ and tetM), macrolides (ermA, ermB, ermC and $m s r A)$, fluoroquinolones ( $g r l A$ and norA), glycopeptides (vanA) and phenicols (ch/A) antibiotic resistance genes. Safarpoor et al. (2017) (Safarpoor Dehkordi et al. 2017a) showed that prevalence of aacA-D, tetK, tetM, msrA, ermA, ermC, vatA, vatB, vatC and linA antibiotic resistance genes in the MRSA strains isolated from food samples in Iran were $62.16 \%, 72.97 \%, 27.02 \%, 64.86 \%, 72.97 \%, 27.02 \%, 45.94 \%, 18.91 \%, 5.40 \%$ and $43.24 \%$, respectively which was similar to our findings. The most imperative mechanism involving resistance against clindamycin is modulated by methylase enzyme which often encoded by ermA and ermC genes (Zelazny et al. 2005). The literature survey did not indicate any report on the prevalence of vatA, vatB, vatC, $m s r A$, ermA, ermC, linA, aacA-D, tetK and tetM genes among the MRSA strains of raw quail, turkey and camel meat samples

\section{Conclusion}

To put it in a nutshell, we identified high prevalence of antibiotic resistance, antibiotic resistance genes, SCCmec types and $P V L$ gene in the MRSA strains isolated from raw ruminants, poultries and fish meat samples. MRSA strains had the higher prevalence in raw sheep and goat meat samples. Additionally, MRSA strains isolated from sheep meat samples harbored higher prevalence of $P V L$ gene, antibiotic resistance gens and SCCmec types. MRSA strains harbored the highest prevalence of resistance against penicillin, tetracycline, gentamicin, erythromycin and trimethoprim-sulfamethoxazole antibiotic agents. Higher prevalence of aadA1, tetK, msrA and vatA antibiotic resistance genes is another important finding. Some MRSA strains exhibited simultaneous resistance against more than one antibiotic agents. Additionally, some of the harbored more than one antibiotic resistance genes. Furthermore, our research demonstrated that most MRSA were found to be resistant to commonly used antimicrobial agents which raised concerns regarding transmission risk following the consumption of raw or undercooked meat. Moreover, raw meat samples were the main sources of CA-MRSA strains with higher prevalence of SCCmec IV and V types. MRSA strains isolated from poultry meat samples harbored the highest prevalence of resistance against chloramphenicol antibiotic agents. Prevalence of resistance against human-based antibiotic was also high. Simultaneous presence of $P V L$ gene, SCCmec types and antibiotic resistance genes in the MRSA strains pose an important public health threat regarding the consumption of raw or undercooked meat samples. As far as we know, the present study is the first report in its field on MRSA strains isolated from camel, turkey and quail meat samples. Our research highlights the importance of monitoring the antimicrobial susceptibility of MRSA in the food chains including raw meat and especially sheep, goat and poultry meat samples and these data could be used proactively to assist government and industries in Iran to develop improved food safety measures, designed to reduce the contamination and transmission of this bacterium. Moreover, a future large-scale and multipopulation-based study must be conducted to obtain more comprehensive data on the prevalence and distribution of MRSA strains in different Iranian ethnic populations.

\section{Abbreviations}

S. aureus: Staphylococcus aureus; MRSA: Methicillin-resistant Staphylococcus aureus, PCR: Polymerase Chain Reaction; SPSS: Statistical Package for the Social Sciences

\section{Declarations}


Availability of data and materials

All data generated or analyzed throughout this research are included in this published article.

\section{Competing interests}

Authors declared that they have no conflict of interest.

\section{Funding}

Funding is not applicable for this research.

\section{Authors' contributions}

Sample collection, microbial analysis, PCR alignment, writing and drafting of the manuscript were performed by the RC.

\section{Acknowledgements}

The authors would like to thank Dr. Manouchehr Momeni Shahraki for his assistance in sample collection and PCR genetic alignments.

\section{References}

Abdalrahman LS, Stanley A, Wells H, Fakhr MK (2015) Isolation, virulence, and antimicrobial resistance of methicillin-resistant Staphylococcus aureus (MRSA) and methicillin sensitive Staphylococcus aureus (MSSA) strains from Oklahoma retail poultry meats. Int J Env Res Pub Health 12(6): 6148-6161.

Agwu Ulu N, Felix EE, Chisom Olachi U, Maduka VA, Onyinye Esther U-I, Okoro Samuel C, M AM (2014) Prevalence of methicillinresistant Staphylococcus aureus (MRSA) in raw meat and meat handlers in Onitsha, Nigeria. European J Prevent Med 2(9-15.

Argudín MÁ, Mendoza MC, Rodicio MR (2010) Food poisoning and Staphylococcus aureus enterotoxins. Toxins 2(7): 17511773.

Asghar A (2014) Molecular characterization of methicillin-resistant Staphylococcus aureus isolated from tertiary care hospitals. Pakistan J Med Sci 30(4): 698-702.

Bartter J, Diffey H, Yeung YH, O'Leary F, Häsler B, Maulaga W, Alders R (2018) Use of chicken eggshell to improve dietary calcium intake in rural sub-S aharan A frica. Maternal Child Nutr 14(e12649.

Beneke B, Klees S, Stührenberg B, Fetsch A, Kraushaar B, Tenhagen B-A (2011) Prevalence of methicillin-resistant Staphylococcus aureus in a fresh meat pork production chain. J Food Protect 74(1): 126-129.

Bhargava K, Wang X, Donabedian S, Zervos M, da Rocha L, Zhang Y (2011) Methicillin-resistant Staphylococcus aureus in retail meat, Detroit, Michigan, USA. Emerg Infect Dis 17(6): 1135.

Chajęcka-Wierzchowska W, Zadernowska A, Łaniewska-Trokenheim $Ł$ (2017) Staphylococcus Aureus From Ready-To-Eat Food As A Source Of Multiple Antibiotic Resistance Genes. CBU International Conference Proceedings. Central Bohemia University, p. 1108.

CLSI (2007) Performance Standards for Antimicrobial Susceptibility Testing; 17th Informational Supplement. CLSI document M100-S17. Clinical and Laboratory Standards Institute.

CLSI (2012) Performance standards for antimicrobial susceptibility testing. Twenty-second informational supplement M100S21. Wayne Pa. Clinical and Laboratory Standards Institute. 
De Boer E, Zwartkruis-Nahuis J, Wit B, Huijsdens X, De Neeling A, Bosch T, Van Oosterom R, Vila A, Heuvelink A (2009) Prevalence of methicillin-resistant Staphylococcus aureus in meat. Int J Food Microbiol 134(1-2): 52-56.

Ferreira FA, Souza RR, de Sousa Moraes B, de Amorim Ferreira AM, Américo MA, Fracalanzza SEL, Couceiro JNdSS, Figueiredo AMS (2013) Impact of Agr dysfunction on virulence profiles and infections associated with a novel methicillin-resistant Staphylococcus aureus (MRSA) variant of the lineage ST1-SCC mec IV. BMC Microbiol 13(93): 1-12.

Feßler AT, Kadlec K, Hassel M, Hauschild T, Eidam C, Ehricht R, Monecke S, Schwarz S (2011) Characterization of methicillinresistant Staphylococcus aureus isolates from food and food products of poultry origin in Germany. App Env Microbiol. 0056100511.

Fijałkowski K, Peitler D, Karakulska J (2016) Staphylococci isolated from ready-to-eat meat-identification, antibiotic resistance and toxin gene profile. Int J Food Microbiol 238(113-120.

Fowoyo P, Ogunbanwo S (2017) Antimicrobial resistance in coagulase-negative staphylococci from Nigerian traditional fermented foods. Ann Clin Microbiol Antimicrob 16(1): 4.

Gundogan N, Citak S, Yucel N, Devren A (2005) A note on the incidence and antibiotic resistance of Staphylococcus aureus isolated from meat and chicken samples. Meat Sci 69(4): 807-810.

Hanson B, Dressler A, Harper A, Scheibel R, Wardyn S, Roberts L, Kroeger J, Smith T (2011) Prevalence of Staphylococcus aureus and methicillin-resistant Staphylococcus aureus (MRSA) on retail meat in lowa. J Infect Pub Health 4(4): 169-174.

Hasanpour Dehkordi A, Khaji L, Sakhaei Shahreza M, Mashak Z, Safarpoor Dehkordi F, Safaee Y, Hosseinzadeh A, Alavi I, Ghasemi E, Rabiei-Faradonbeh M (2017) One-year prevalence of antimicrobial susceptibility pattern of methicillin-resistant Staphylococcus aureus recovered from raw meat. Tropic Biomed 34(2): 396-404.

Holmes A, Ganner M, McGuane S, Pitt T, Cookson B, Kearns A (2005) Staphylococcus aureus isolates carrying Panton-Valentine leucocidin genes in England and Wales: frequency, characterization, and association with clinical disease. J Clin Microbiol 43(5): 2384-2390.

Huber H, Koller S, Giezendanner N, Stephan R, Zweifel C (2010) Prevalence and characteristics of meticillin-resistant Staphylococcus aureus in humans in contact with farm animals, in livestock, and in food of animal origin, Switzerland, 2009. Eurosurveillance 15(16): 1-4.

Jackson CR, Davis JA, Barrett JB (2013) Prevalence and characterization of methicillin-resistant Staphylococcus aureus isolates from retail meat and humans in Georgia. J Clin Microbiol 51(4): 1199-1207.

Johnson AP (2011) Methicillin-resistant Staphylococcus aureus: the European landscape. J Antimicrob Chemotherap 66(suppl_4): iv43-iv48.

Kadariya J, Smith TC, Thapaliya D (2014) Staphylococcus aureus and staphylococcal food-borne disease: an ongoing challenge in public health. BioMed Res Int 2014(

Karmi M (2013) Prevalence of methicillin-resistant Staphylococcus aureus in poultry meat in Qena, Egypt. Vet World 6(10): 711715.

Klevens RM, Morrison MA, Nadle J, Petit S, Gershman K, Ray S, Harrison LH, Lynfield R, Dumyati G, Townes JM (2007) Invasive methicillin-resistant Staphylococcus aureus infections in the United States. Jama 298(15): 1763-1771.

Kreausukon K, Fetsch A, Kraushaar B, Alt K, Müller K, Krömker V, Zessin K-H, Käsbohrer A, Tenhagen B-A (2012) Prevalence, antimicrobial resistance, and molecular characterization of methicillin-resistant Staphylococcus aureus from bulk tank milk of dairy herds. J Dairy Sci 95(8): 4382-4388. 
Kroning IS, Iglesias MA, Sehn CP, Gandra TKV, Mata MM, da Silva WP (2016) Staphylococcus aureus isolated from handmade sweets: biofilm formation, enterotoxigenicity and antimicrobial resistance. Food Microbiol 58(105-111.

Lazzaroni C, Gigli S, Gabiña D (2007) Evaluation of Carcass and Meat Quality in Cattle and Sheep. Wageningen Academic Pub, Netherlands.

Lim S-K, Nam H-M, Park H-J, Lee H-S, Choi M-J, Jung S-C, Lee J-Y, Kim Y-C, Song S-W, Wee S-H (2010) Prevalence and characterization of methicillin-resistant Staphylococcus aureus in raw meat in Korea. J Microbiol Biotech 20(4): 775-778.

Lina G, Quaglia A, Reverdy M-E, Leclercq R, Vandenesch F, Etienne J (1999) Distribution of genes encoding resistance to macrolides, lincosamides, and streptogramins among staphylococci. Antimicrob Agent Chemotherap 43(5): 1062-1066.

Lozano C, López M, Gómez-Sanz E, Ruiz-Larrea F, Torres C, Zarazaga M (2009) Detection of methicillin-resistant Staphylococcus aureus ST398 in food samples of animal origin in Spain. J Antimicrob Chemotherap 64(6): 1325-1326.

Madahi H, Rostami F, Rahimi E, Dehkordi FS (2014) Prevalence of enterotoxigenic Staphylococcus aureus isolated from chicken nugget in Iran. Jundishapur J Microbiol 7(8).

Momtaz H, Dehkordi FS, Rahimi E, Asgarifar A, Momeni M (2013) Virulence genes and antimicrobial resistance profiles of Staphylococcus aureus isolated from chicken meat in Isfahan province, Iran. J App Poultry Res 22(4): 913-921.

Momtaz H, Hafezi L (2014) Meticillin-resistant Staphylococcus aureus isolated from Iranian hospitals: virulence factors and antibiotic resistance properties. Bosnian J Basic Med Sci 14(4): 219.

Morell EA, Balkin DM (2010) Methicillin-resistant Staphylococcus aureus: a pervasive pathogen highlights the need for new antimicrobial development. Yale J Bio Med 83(4): 223-233.

Ogata K, Narimatsu H, Suzuki M, Higuchi W, Yamamoto T, Taniguchi H (2012) Commercially distributed meat as a potential vehicle for community-acquired methicillin-resistant Staphylococcus aureus. App Env Microbiol 2797-2802.

Paludi D, Vergara A, Festino AR, Di Ciccio P, Costanzo C, Conter M, Zanardi E, Ghidini S, lanieri A (2011) Antimicrobial resistance pattern of methicillin-resistant Staphylococcus aureus in the food industry. J Biol Regulat Homeost Agent 25(4): 671.

Pu S, Han F, Ge B (2009) Isolation and characterization of methicillin-resistant Staphylococcus aureus strains from Louisiana retail meats. App Env Microbiol 75(1): 265-267.

Richter A, Sting R, Popp C, Rau J, Tenhagen B-A, Guerra B, Hafez H, Fetsch A (2012) Prevalence of types of methicillin-resistant Staphylococcus aureus in turkey flocks and personnel attending the animals. Epidemiol Infect 140(12): 2223-2232.

Safarpoor Dehkordi F, Akhondzadeh Basti A, Gandomi H, Misaghi A, Rahimi E (2018) Pathogenic Staphylococcus aureus in hospital food samples; prevalence and antimicrobial resistance properties. J Food Safetye12501.

Safarpoor Dehkordi F, Gandomi H, Akhondzadeh Basti A, Misaghi A, Rahimi E (2017a) Phenotypic and genotypic characterization of antibiotic resistance of methicillin-resistant Staphylococcus aureus isolated from hospital food. Antimicrob Resist Infect Control 6(1): 104.

Safarpoor Dehkordi F, Gandomi H, Akhondzadeh Basti A, Misaghi A, Rahimi E (2017b) Phenotypic and genotypic characterization of antibiotic resistance of methicillin-resistant Staphylococcus aureus isolated from hospital food. Antimicrob Resist Infect Control 6(104-104.

Sallam KI, Abd-Elghany SM, Elhadidy M, Tamura T (2015) Molecular characterization and antimicrobial resistance profile of methicillin-resistant Staphylococcus aureus in retail chicken. J Food Protect 78(10): 1879-1884. 
Scallan E, Hoekstra RM, Angulo FJ, Tauxe RV, Widdowson M-A, Roy SL, Jones JL, Griffin PM (2011) Foodborne illness acquired in the United States-major pathogens. Emerging Infect Dis 17(1): 7.

Shahraz F, Dadkhah H, Khaksar R, Mahmoudzadeh M, Hosseini H, Kamran M, Bourke P (2012) Analysis of antibiotic resistance patterns and detection of mecA gene in Staphylococcus aureus isolated from packaged hamburger. Meat Sci 90(3): 759-763.

Shen H, Akoda E, Zhang K (2013) Methicillin-resistant Staphylococcus aureus carriage among students at a historically black university: a case study. Int J Microbiol 2013(1-7.

Shrestha B, Singh W, Raj VS, Pokhrel BM, Mohapatra TM (2014) High prevalence of Panton-Valentine leukocidin (PVL) genes in nosocomial-acquired Staphylococcus aureus isolated from tertiary care hospitals in Nepal. BioMed Res Int 2014(1-7.

Shukla SK, Pantrangi M, Stahl B, Briska AM, Stemper ME, Wagner TK, Zentz EB, Callister SM, Lovrich SD, Henkhaus JK (2012) Comparative whole genome mapping to determine Staphylococcus aureus genome size, virulence motifs and clonality. J Clin Microbiol 50(11): $3526-3533$.

Strommenger B, Kettlitz C, Werner G, Witte W (2003) Multiplex PCR assay for simultaneous detection of nine clinically relevant antibiotic resistance genes in Staphylococcus aureus. J Clin Microbiol 41(9): 4089-4094.

Tang Y, Larsen J, Kjeldgaard J, Andersen PS, Skov R, Ingmer H (2017) Methicillin-resistant and-susceptible Staphylococcus aureus from retail meat in Denmark. International J Food Microbiol 249(72-76.

Turlej A, Hryniewicz W, Empel J (2011) Staphylococcal cassette chromosome mec (Sccmec) classification and typing methods: an overview. Pol J Microbiol 60(2): 95-103.

Udo EE, Al-Mufti S, Albert MJ (2009) The prevalence of antimicrobial resistance and carriage of virulence genes in Staphylococcus aureus isolated from food handlers in Kuwait City restaurants. BMC Res Note 2(1): 108.

Velasco V, Sherwood JS, Rojas-García PP, Logue CM (2014) Multiplex real-time PCR for detection of Staphylococcus aureus, mecA and Panton-Valentine Leukocidin (PVL) genes from selective enrichments from animals and retail meat. PloS One 9(5): e97617.

Vossenkuhl B, Brandt J, Fetsch A, Käsbohrer A, Kraushaar B, Alt K, Tenhagen B-A (2014) Comparison of spa types, SCCmec types and antimicrobial resistance profiles of MRSA isolated from turkeys at farm, slaughter and from retail meat indicates transmission along the production chain. PloS One 9(5): e96308.

Waters AE, Contente-Cuomo T, Buchhagen J, Liu CM, Watson L, Pearce K, Foster JT, Bowers J, Driebe EM, Engelthaler DM (2011) Multidrug-resistant Staphylococcus aureus in US meat and poultry. Clin Infect Dis 52(10): 1227-1230.

Weese J, Avery B, Reid-Smith R (2010) Detection and quantification of methicillin-resistant Staphylococcus aureus (MRSA) clones in retail meat products. Letter App Microbiol 51(3): 338-342.

Yamasaki O, Kaneko J, Morizane S, Akiyama H, Arata J, Narita S, Chiba J-i, Kamio Y, Iwatsuki K (2005) The association between Staphylococcus aureus strains carrying Panton-Valentine leukocidin genes and the development of deep-seated follicular infection. Clin Infect Dis 40(3): 381-385.

Zelazny AM, Ferraro MJ, Glennen A, Hindler JF, Mann LM, Munro S, Murray PR, Reller LB, Tenover FC, Jorgensen JH (2005) Selection of strains for quality assessment of the disk induction method for detection of inducible clindamycin resistance in staphylococci: a CLSI collaborative study. J Clin Microbiol 43(6): 2613-2615.

Zhang K, McClure J-A, Elsayed S, Louie T, Conly JM (2005) Novel multiplex PCR assay for characterization and concomitant subtyping of staphylococcal cassette chromosome mec types I to V in methicillin-resistant Staphylococcus aureus. J Clin Microbiol 43(10): 5026-5033.

Page 10/16 


\section{Tables}

Table 1. Target enterotoxin genes, oligonucleotide primers, PCR programs and volumes used for detection of antibiotic resistance genes and SCCmec types amongst the MRSA strains isolated from various types of raw meat samples. 


\begin{tabular}{|c|c|c|c|c|}
\hline $\begin{array}{l}\text { Target } \\
\text { gene }\end{array}$ & Primer sequence (5'-3') & $\begin{array}{l}\text { PCR product } \\
\text { (bp) }\end{array}$ & PCR programs & PCR volume $(50 \mu \mathrm{L})$ \\
\hline \multirow[t]{2}{*}{$A a c A-D$} & F: TAATCCAAGAGCAATAAGGGC & \multirow[t]{2}{*}{227} & \multirow{9}{*}{ 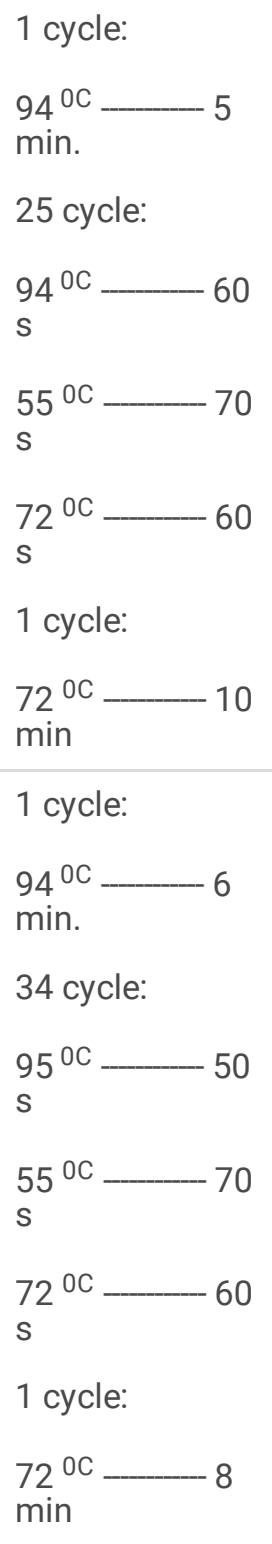 } & $5 \mu \mathrm{L}$ PCR buffer $10 \mathrm{X}$ \\
\hline & R: GCCACACTATCATAACCACTA & & 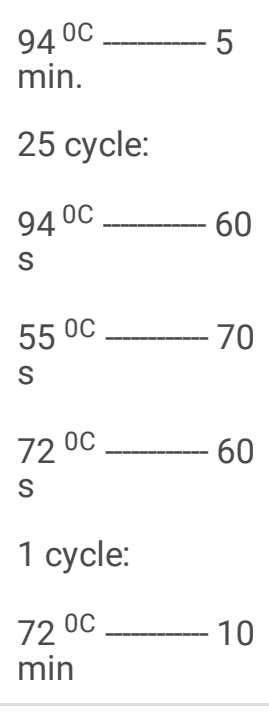 & \multirow{9}{*}{$\begin{array}{l}2 \mathrm{mM} \mathrm{Mgcl}_{2} \\
150 \mu \mathrm{M} \text { dNTP } \\
0.75 \mu \mathrm{M} \text { of each primers } \\
\mathrm{F} \& \mathrm{R} \\
1.5 \mathrm{U} \text { Taq DNA } \\
\text { polymerase } \\
3 \mu \mathrm{L} \text { DNA template }\end{array}$} \\
\hline \multirow[t]{2}{*}{ ermA } & F: AAGCGGTAAACCCCTCTGA & \multirow[t]{2}{*}{190} & \multirow{4}{*}{$\begin{array}{l}25 \text { cycle: } \\
94^{\mathrm{OC}}-60 \\
\mathrm{~s} \\
55^{\mathrm{OC}}-70 \\
\mathrm{~s} \\
72^{\mathrm{OC}}-60 \\
\mathrm{~s} \\
1 \text { cycle: } \\
72^{\mathrm{OC}} 10 \\
\mathrm{~min}\end{array}$} & \\
\hline & R: TTCGCAAATCCCTTCTCAAC & & & \\
\hline \multirow[t]{2}{*}{ ermC } & F: AATCGTCAATTCCTGCATGT & \multirow[t]{2}{*}{299} & & \\
\hline & R: TAATCGTGGAATACGGGTTTG & & & \\
\hline \multirow[t]{2}{*}{ tetK } & F: GTAGCGACAATAGGTAATAGT & \multirow[t]{2}{*}{360} & \multirow{4}{*}{$\begin{array}{l}72^{\circ \mathrm{CC}}-60 \\
\mathrm{~s} \\
1 \text { cycle: } \\
72^{\mathrm{OC}}-10 \\
\min \end{array}$} & \\
\hline & R: GTAGTGACAATAAACCTCCTA & & & \\
\hline \multirow[t]{2}{*}{ vatC } & F: AAAATCGATGGTAAAGGTTGGC & \multirow[t]{2}{*}{467} & & \\
\hline & R: AGTTCTGCAGTACCGGATTTGC & & & \\
\hline \multirow[t]{4}{*}{ tetM } & F: AGTGGAGCGATTACAGAA & \multirow[t]{4}{*}{158} & & \multirow{4}{*}{$\begin{array}{l}5 \mu \mathrm{L} \text { PCR buffer } 10 \mathrm{X} \\
2 \mathrm{mM} \mathrm{Mgcl}_{2} \\
150 \mu \mathrm{M} \text { dNTP } \\
0.75 \mu \mathrm{M} \text { of each primers } \\
\mathrm{F} \& \mathrm{R} \\
1.5 \mathrm{U} \text { Taq DNA }\end{array}$} \\
\hline & R: CATATGTCCTGGCGTGTCTA & & & \\
\hline & & & & \\
\hline & & & & \\
\hline \multirow[t]{4}{*}{ vatA } & F: TGGTCCCGGAACAACATTTAT & \multirow[t]{4}{*}{268} & & polymerase \\
\hline & R: TCCACCGACAATAGAATAGGG & & & \\
\hline & & & & \\
\hline & & & & \\
\hline \multirow[t]{5}{*}{ msrA } & F: GGCACAATAAGAGTGTTTAAAGG & \multirow[t]{5}{*}{940} & \multirow{5}{*}{$\begin{array}{l}1 \text { cycle: } \\
94^{\mathrm{OC}}-6 \\
\text { min. } \\
34 \text { cycle: } \\
95^{\mathrm{OC}}-60 \\
\mathrm{~s}\end{array}$} & $5 \mu \mathrm{L}$ PCR buffer $10 \mathrm{X}$ \\
\hline & $\begin{array}{l}\text { R: } \\
\text { AAGTTATATCATGAATAGATTGTCCTGTT }\end{array}$ & & & \\
\hline & & & & \\
\hline & & & & $\begin{array}{l}0.75 \mu \mathrm{M} \text { of each primers } \\
\mathrm{F} \& \mathrm{R}\end{array}$ \\
\hline & & & & 1.5 U Taq DNA \\
\hline \multirow[t]{4}{*}{$m s r B$} & F: TATGATATCCATAATAATTATCCAATC & \multirow[t]{4}{*}{595} & $\begin{array}{l}5000 \\
s\end{array}$ & \\
\hline & $\begin{array}{l}\text { R: } \\
\text { AAGTTATATCATGAATAGATTGTCCTGTT }\end{array}$ & & $72^{0 C}-70$ & \\
\hline & & & 1 cycle: & \\
\hline & & & $\begin{array}{l}72^{\circ \mathrm{C}}-8 \\
\min \end{array}$ & \\
\hline vatB & F: GCTGCGAATTCAGTTGTTACA & 136 & 1 cycle: & $5 \mu \mathrm{L}$ PCR buffer $10 \mathrm{X}$ \\
\hline
\end{tabular}




\begin{tabular}{|c|c|c|c|c|}
\hline & R: CTGACCAATCCCACCATTTTA & & 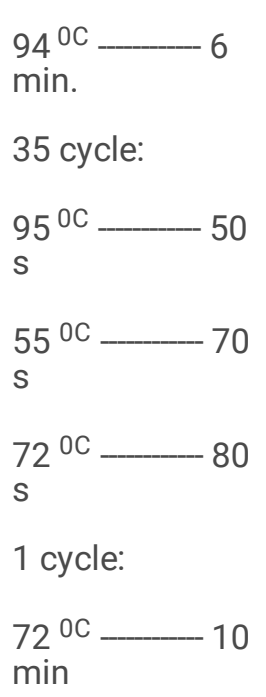 & $\begin{array}{l}2 \mathrm{mM} \mathrm{Mgcl}_{2} \\
150 \mu \mathrm{M} \text { dNTP } \\
0.75 \mu \mathrm{M} \text { of each primers } \\
\mathrm{F} \& \mathrm{R} \\
1.5 \mathrm{U} \text { Taq DNA } \\
\text { polymerase } \\
3 \mu \mathrm{L} \text { DNA template }\end{array}$ \\
\hline $\operatorname{lin} A$ & $\begin{array}{l}\text { F: } \\
\text { GGTGGCTGGGGGGTAGATGTATTAACTGG } \\
\text { R: } \\
\text { GCTTCTTTTGAAATACATGGTATTTTTCGA }\end{array}$ & 323 & 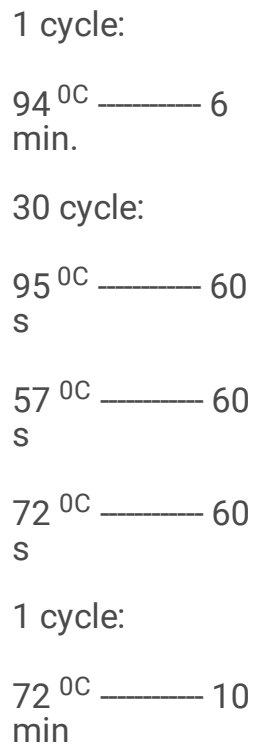 & $\begin{array}{l}5 \mu \mathrm{L} \text { PCR buffer } 10 \mathrm{X} \\
2 \mathrm{mM} \mathrm{Mgcl} 2 \\
150 \mu \mathrm{M} \text { dNTP } \\
0.75 \mu \mathrm{M} \text { of each primers } \\
\mathrm{F} \& \mathrm{R} \\
1.5 \mathrm{U} \text { Taq DNA } \\
\text { polymerase } \\
3 \mu \mathrm{L} \text { DNA template }\end{array}$ \\
\hline scCmec I & $\begin{array}{l}\text { F: GCTTTAAAGAGTGTCGTTACAGG } \\
\text { R: GTTCTCTCATAGTATGACGTCC }\end{array}$ & 613 & $\begin{array}{l}1 \text { cycle: } \\
94^{\mathrm{OC}}+5\end{array}$ & $\begin{array}{l}5 \mu \mathrm{L} \text { PCR buffer } 10 \mathrm{X} \\
2 \mathrm{mM} \mathrm{Mgcl}_{2}\end{array}$ \\
\hline scCmec II & $\begin{array}{l}\text { F: CGTTGAAGATGATGAAGCG } \\
\text { R: CGAAATCAATGGTTAATGGACC }\end{array}$ & 398 & 10 cycle: & $\begin{array}{l}150 \mu \mathrm{M} \text { dNTP } \\
0.75 \mu \mathrm{M} \text { of each primers }\end{array}$ \\
\hline $\begin{array}{l}\text { SCCmec } \\
\text { III }\end{array}$ & $\begin{array}{l}\text { F: CCATATTGTGTACGATGCG } \\
\text { R: CCTTAGTTGTCGTAACAGATCG }\end{array}$ & 280 & $\begin{array}{l}94^{\mathrm{OC}}-45 \\
\mathrm{~s}-45^{\mathrm{OC}} \longrightarrow-45\end{array}$ & $\begin{array}{l}1.5 \cup \text { Taq DNA } \\
\text { polymerase }\end{array}$ \\
\hline $\begin{array}{l}\text { SCCmec } \\
\text { IVa }\end{array}$ & $\begin{array}{l}\text { F: GCCTTATTCGAAGAAACCG } \\
\text { R: CTACTCTTCTGAAAAGCGTCG }\end{array}$ & 776 & $\begin{array}{l}s \\
70 \text { oc }-90\end{array}$ & $3 \mu \mathrm{L}$ DNA template \\
\hline $\begin{array}{l}\text { SCCmec } \\
\text { IVb }\end{array}$ & $\begin{array}{l}\text { F: TCTGGAATTACTTCAGCTGC } \\
\text { R: AAACAATATTGCTCTCCСTC }\end{array}$ & 493 & 1 cycle: & \\
\hline $\begin{array}{l}\text { SCCmec } \\
\text { IVc }\end{array}$ & $\begin{array}{l}\text { F: ACAATATTTGTATTATCGGAGAGC } \\
\text { R: TTGGTATGAGGTATTGCTGG }\end{array}$ & 200 & $\min =10$ & \\
\hline $\begin{array}{l}\text { SCCmec } \\
\text { IVd }\end{array}$ & $\begin{array}{l}\text { F: CTCAAAATACGGACCCCAATACA } \\
\text { R: TGCTCCAGTAATTGCTAAAG }\end{array}$ & 881 & & \\
\hline scCmec $V$ & F: GAACATTGTTACTTAAATGAGCG & 325 & & \\
\hline
\end{tabular}


Table 2. Total distribution of MRSA and $P V L$ gene in various types of raw meat samples.

\begin{tabular}{|lllll|}
\hline $\begin{array}{l}\text { Types of } \\
\text { samples }\end{array}$ & $\begin{array}{l}\text { No. samples } \\
\text { collected }\end{array}$ & $\begin{array}{l}\text { No. samples positive for } \text { S. } \\
\text { aureus }(\%)\end{array}$ & $\begin{array}{l}\text { No. samples positive for } \\
\text { MRSA (\%) }\end{array}$ & $\begin{array}{l}\text { PVL positive } \\
(\%)\end{array}$ \\
\hline Beef & 150 & $30(20)$ & $17(56.66)$ & $12(70.58)$ \\
\hline Goat & 80 & $15(18.75)$ & $10(66.66)$ & $7(70)$ \\
\hline Sheep & 100 & $28(28)$ & $21(75)$ & $20(95.23)$ \\
\hline Camel & 60 & $8(13.33)$ & $4(50)$ & $2(50)$ \\
\hline Chicken & 80 & $20(25)$ & $7(63.63)$ & $10(83.33)$ \\
\hline Turkey & 50 & $11(22)$ & $3(60)$ & $4(57.14)$ \\
\hline Quail & 50 & $5(10)$ & $5(71.42)$ & $1(33.33)$ \\
\hline Ostrich & 50 & $7(14)$ & - & $2(40)$ \\
\hline Fish & 60 & $1(1.66)$ & $79(63.20)$ & - \\
\hline Total & 680 & $125(18.38)$ & & $58(73.41)$ \\
\hline
\end{tabular}

Table 3. Distribution of SCCmec types in MRSA strains isolated from various types of raw meat samples.

\begin{tabular}{|c|c|c|c|c|c|c|c|c|}
\hline \multirow{2}{*}{$\begin{array}{l}\text { Type of samples (No. } \\
\text { MRSA) }\end{array}$} & \multicolumn{8}{|c|}{$\mathrm{N}(\%)$ isolates positive for each type } \\
\hline & ${ }_{I}^{\text {scCmec }}$ & $\begin{array}{l}\text { scCmec } \\
\text { II }\end{array}$ & $\begin{array}{l}\text { SCCmec } \\
\text { III }\end{array}$ & $\begin{array}{l}\text { SCCmec } \\
\text { IVa }\end{array}$ & $\begin{array}{l}\text { scCmec } \\
\text { IVb }\end{array}$ & $\begin{array}{l}\text { SCCmec } \\
\text { IVc }\end{array}$ & $\begin{array}{l}\text { SCCmec } \\
\text { IVd }\end{array}$ & $\begin{array}{l}\text { SCCmec } \\
V\end{array}$ \\
\hline Beef (12) & $1(8.33)$ & - & $\begin{array}{l}2 \\
(16.66)\end{array}$ & $4(33.33)$ & $1(8.33)$ & - & $2(16.66)$ & $\begin{array}{l}2 \\
(16.66)\end{array}$ \\
\hline Goat (7) & $\begin{array}{l}1 \\
(14.28)\end{array}$ & - & $\begin{array}{l}1 \\
(14.28)\end{array}$ & $3(42.85)$ & - & - & - & $\begin{array}{l}2 \\
(28.57)\end{array}$ \\
\hline Sheep (20) & $2(10)$ & $1(5)$ & $2(10)$ & $8(40)$ & $1(5)$ & $1(5)$ & $1(5)$ & $4(20)$ \\
\hline Camel (2) & - & - & - & $1(50)$ & - & - & - & $1(50)$ \\
\hline Chicken (10) & $1(10)$ & - & $1(10)$ & $3(30)$ & $1(10)$ & $1(10)$ & $1(10)$ & $2(20)$ \\
\hline Turkey (4) & - & - & - & $2(50)$ & $1(25)$ & - & - & $1(25)$ \\
\hline Quail (1) & - & - & - & $1(100)$ & - & - & - & - \\
\hline Ostrich (2) & - & - & - & $1(50)$ & - & - & - & $1(50)$ \\
\hline Total (58) & $5(8.62)$ & $1(1.72)$ & $\begin{array}{l}6 \\
(10.34)\end{array}$ & $\begin{array}{l}23 \\
(39.65)\end{array}$ & 4 (6.89) & $2(3.44)$ & $4(6.89)$ & $\begin{array}{l}13 \\
(22.41)\end{array}$ \\
\hline
\end{tabular}

Table 4. Antibiotic resistance pattern of the MRSA isolated from various types of raw meat samples. 


\begin{tabular}{|c|c|c|c|c|c|c|c|c|c|c|}
\hline \multirow{2}{*}{$\begin{array}{l}\text { Type of samples } \\
\text { (No. MRSA) }\end{array}$} & \multicolumn{10}{|c|}{$\mathrm{N}(\%)$ isolates resistant to each antibiotic agent } \\
\hline & $\mathrm{P} 10^{*}$ & Gen & Azi & Ert & Tet & Dox & Cip & Clin & Tr-Sul & $\mathrm{C} 30$ \\
\hline Beef (12) & $\begin{array}{l}12 \\
(100)\end{array}$ & $9(75)$ & $\begin{array}{l}7 \\
(58.33)\end{array}$ & $\begin{array}{l}8 \\
(66.66)\end{array}$ & $\begin{array}{l}12 \\
(100)\end{array}$ & $\begin{array}{l}5 \\
(41.66)\end{array}$ & $6(50)$ & $\begin{array}{l}5 \\
(41.66)\end{array}$ & $\begin{array}{l}8 \\
(66.66)\end{array}$ & $\begin{array}{l}2 \\
(16.66)\end{array}$ \\
\hline Goat (7) & $\begin{array}{l}7 \\
(100)\end{array}$ & $\begin{array}{l}4 \\
(57.14)\end{array}$ & $\begin{array}{l}3 \\
(42.85)\end{array}$ & $\begin{array}{l}3 \\
(42.85)\end{array}$ & $\begin{array}{l}7 \\
(100)\end{array}$ & $\begin{array}{l}3 \\
(42.85)\end{array}$ & $\begin{array}{l}3 \\
(42.85)\end{array}$ & $\begin{array}{l}2 \\
(28.57)\end{array}$ & $\begin{array}{l}4 \\
(57.14)\end{array}$ & $\begin{array}{l}1 \\
(14.28)\end{array}$ \\
\hline Sheep (20) & $\begin{array}{l}20 \\
(100)\end{array}$ & $15(75)$ & $12(60)$ & $14(70)$ & $\begin{array}{l}20 \\
(100)\end{array}$ & $10(50)$ & $8(40)$ & $7(35)$ & $11(55)$ & $1(5)$ \\
\hline Camel (2) & $\begin{array}{l}2 \\
(100)\end{array}$ & $1(50)$ & - & $1(50)$ & $\begin{array}{l}2 \\
(100)\end{array}$ & - & - & - & $1(50)$ & - \\
\hline Chicken (10) & $\begin{array}{l}10 \\
(100)\end{array}$ & $6(60)$ & $4(40)$ & $4(40)$ & $\begin{array}{l}10 \\
(100)\end{array}$ & $4(40)$ & $3(30)$ & $3(30)$ & $5(50)$ & $6(30)$ \\
\hline Turkey (4) & $\begin{array}{l}4 \\
(100)\end{array}$ & $2(50)$ & $1(25)$ & $2(50)$ & $\begin{array}{l}4 \\
(100)\end{array}$ & $1(25)$ & $1(25)$ & - & $2(50)$ & $3(75)$ \\
\hline Quail (1) & $\begin{array}{l}1 \\
(100)\end{array}$ & - & - & - & $\begin{array}{l}1 \\
(100)\end{array}$ & - & - & - & - & $1(100)$ \\
\hline Ostrich (2) & $\begin{array}{l}2 \\
(100)\end{array}$ & $1(50)$ & $1(50)$ & $1(50)$ & $\begin{array}{l}2 \\
(100)\end{array}$ & - & $1(50)$ & - & $1(50)$ & $1(50)$ \\
\hline Total (58) & $\begin{array}{l}58 \\
(100)\end{array}$ & $\begin{array}{l}38 \\
(65.51)\end{array}$ & $\begin{array}{l}28 \\
(48.27)\end{array}$ & $\begin{array}{l}33 \\
(56.89)\end{array}$ & $\begin{array}{l}58 \\
(100)\end{array}$ & $\begin{array}{l}23 \\
(39.65)\end{array}$ & $\begin{array}{l}22 \\
(37.93)\end{array}$ & $\begin{array}{l}17 \\
(29.31)\end{array}$ & $\begin{array}{l}32 \\
(55.17)\end{array}$ & $\begin{array}{l}15 \\
(25.86)\end{array}$ \\
\hline
\end{tabular}

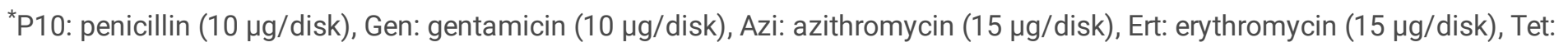
tetracycline (30 $\mu \mathrm{g} / \mathrm{disk})$, Do: doxycycline (30 $\mu \mathrm{g} / \mathrm{disk})$, Cip: ciprofloxacin $(5 \mu \mathrm{g} / \mathrm{disk})$, Clin: clindamycin $(2 \mu \mathrm{g} / \mathrm{disk}), \mathrm{Tr}-\mathrm{Sul}$ : trimethoprim-sulfamethoxazole ( $25 \mu \mathrm{g} /$ disk) and C30: chloramphenicol ( $30 \mu \mathrm{g} / \mathrm{disk})$.

Table 5. Distribution of antibiotic resistance genes amongst the MRSA strains isolated from various types of raw meat samples. 


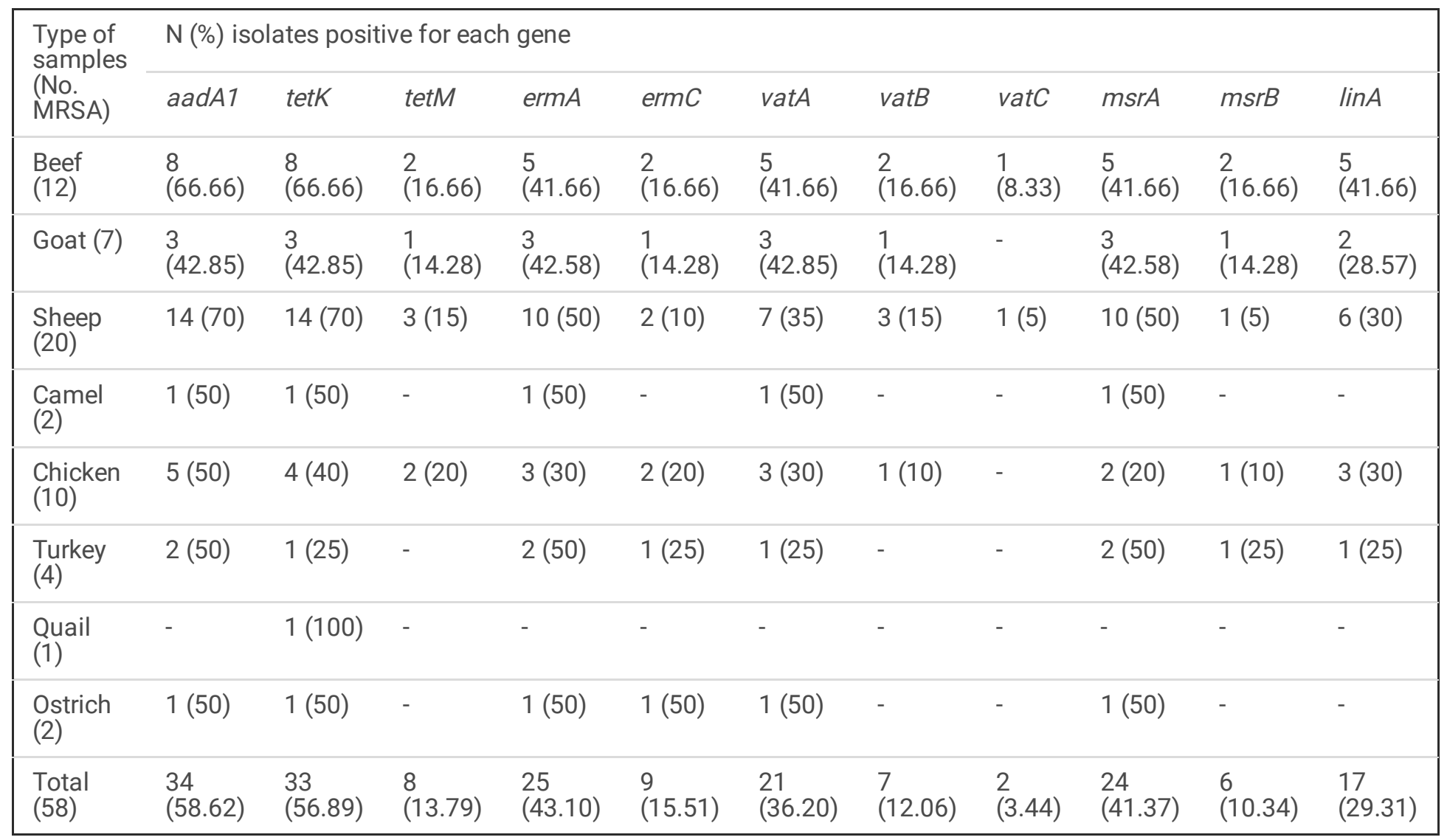

Page 16/16 